\title{
Detection and quantification of the crayfish plague agent in natural waters: direct monitoring approach for aquatic environments
}

\author{
David A. Strand ${ }^{1,2}$, Arne Holst-Jensen ${ }^{1}$, Hildegunn Viljugrein $^{3}$, Bente Edvardsen ${ }^{4}$, \\ Dag Klaveness $^{2}$, Japo Jussila ${ }^{5}$, Trude Vrålstad ${ }^{1,2, *}$
}

\begin{abstract}
${ }^{1}$ Section of Mycology, Norwegian Veterinary Institute, Pb 750, Sentrum, 0106 Oslo, Norway
${ }^{2}$ Microbial Evolution Research Group (MERG), Department of Biology, University of Oslo, Pb 1066, Blindern, 0316 Oslo, Norway

${ }^{3}$ Section of Epidemiology, Norwegian Veterinary Institute, Pb 750, Sentrum, 0106 Oslo, Norway

${ }^{4}$ Marine Biology, Department of Biology, University of Oslo, Pb 1066, Blindern, 0316 Oslo, Norway

${ }^{5}$ Department of Biosciences, University of Eastern Finland, Kuopio campus, PL 1627, 70211 Kuopio, Finland
\end{abstract}

\begin{abstract}
Aphanomyces astaci, a specialised parasite of North American freshwater crayfish, is the disease agent of crayfish plague that is lethal to European freshwater crayfish. The life cycle of A. astaci has been inferred from experimental laboratory studies, but less is known about its natural sustainability and ecology. To address such questions, tools for monitoring of $A$. astaci directly in aquatic environments are needed. Here, we present an approach for detecting and quantifying A. astaci directly from water samples using species-specific TaqMan ${ }^{\circledR}$ minor groove binder real-time PCR. Samples of a 10-fold dilution series from $\sim 10^{4}$ to $\sim 1$ spore of A. astaci were repeatedly tested, and reliable detection down to 1 spore was demonstrated. Further, to simulate real-life samples from natural water bodies, water samples from lakes of various water qualities were spiked with spores. The results demonstrated that co-extracted humic acids inhibit detection significantly. However, use of bovine serum albumin or the TaqMan ${ }^{\circledR}$ Environmental Master Mix largely removes this problem. The practical application of the approach was successfully demonstrated on real-life water samples from crayfish farms in Finland hosting infected North American signal crayfish Pacifastacus leniusculus. Direct monitoring of $A$. astaci from aquatic environments may find application in the management of wild noble crayfish Astacus astacus stocks, improved aquaculture practices and more targeted conservation actions. The approach will further facilitate studies of $A$. astaci spore dynamics during plague outbreaks and in carrier crayfish populations, which will broaden our knowledge of the biology of this devastating crayfish pathogen.
\end{abstract}

KEY WORDS: Aphanomyces astaci · Crayfish plague - Filtration - Molecular detection . Aquatic environments · Quantitative real-time PCR

\section{INTRODUCTION}

The crayfish plague agent Aphanomyces astaci (Saprolegniaceae, Oomycota) is lethal to freshwater crayfish that are not of North American origin (Unestam 1972, Söderhall \& Cerenius 1999). Since Aphanomyces astaci was introduced to Europe in the late 19th century, indigenous crayfish populations have suffered heavy losses, and are still severely threatened (Holdich et al. 2009). Reproduction and spread of Aphanomyces astaci is accomplished by clonal, flagellated zoospores, which remain motile for up to $3 \mathrm{~d}$ and locate new crayfish hosts by chemotaxis. Failure to reach a crayfish host results in encystment of the zoospore (Söderhall \& Cerenius 1999). The cysts may survive for $2 \mathrm{wk}$ in distilled water (Unestam 1969), and 3 repeated zoospore emergences have been observed under laboratory conditions (Cerenius \& Söderhall 1984), but spore via- 
bility and longevity may be prolonged at low temperatures (Unestam 1966). Prevailing evidence shows that Aphanomyces astaci is an obligate crayfish parasite not capable of surviving for a long period outside a crayfish host (Söderhall \& Cerenius 1999). It is also generally accepted that Aphanomyces astaci causes $100 \%$ mortality in susceptible crayfish species. Consequently, Aphanomyces astaci may disappear relatively quickly from a freshwater environment in the absence of live crayfish hosts. This is supported by examples of successful reestablishment of European crayfish into water systems $1 \mathrm{yr}$ after the original population was wiped out by crayfish plague (Söderhall \& Cerenius 1999). However, there are examples of recurring outbreaks of crayfish plague after reintroductions of indigenous crayfish, despite years with no known crayfish in the water system. It is uncertain if this is due to reintroduction of crayfish plague, presence of unknown carrier crayfish or prolonged survival of Aphanomyces astaci in the environment (Westman 2000). The possibility that Aphanomyces astaci may have alternate hosts also needs to be thoroughly tested. In Norway, crayfish plague has reappeared several times in the same localities after a long fallow period before reintroduction of new crayfish (Vrålstad et al. 2006). In one case, illegally introduced signal crayfish Pacifastacus leniusculus infected with Aphanomyces astaci (Johnsen \& Vrålstad 2009) explained the repeated crayfish-plague outbreaks and failure to reintroduce noble crayfish Astacus astacus. However, in other cases it is unknown whether the repeated events are due to undiscovered alien carrier crayfish or other complex factors (Vrålstad et al. 2006). In Finland, crayfish plague has apparently survived in the same water body for 10 to $25 \mathrm{yr}$ and in some cases totally prevented the formation of new, utilisable crayfish populations (Jussila et al. 2008). It has also been shown under laboratory conditions that Aphanomyces astaci is able to complete all stages of its life cycle on fresh fish scales (Hall \& Unestam 1980). Hence, many questions on the ecology of Aphanomyces astaci remain unanswered, and laboratory studies may poorly reflect the survival and persistence of Aphanomyces astaci under complex, natural conditions.

The development of PCR and real-time PCR methods for the specific detection of Aphanomyces astaci has accelerated the speed and significantly improved the accuracy of crayfish-plague diagnostics compared to culture-dependent approaches (Oidtmann et al. 2002, 2004, 2006, Hochwimmer et al. 2009, Vrålstad et al. 2009). Fast and reliable diagnostics of crayfish plague is important when considering countermeasures to prevent further spread of the disease. Furthermore, knowledge of the actual spore dynamics of A. astaci in lakes would be of great importance for jus- tified assessments and decisions during and after plague outbreaks. Infection risk assessments, management of carrier crayfish populations, and evaluations of localities prior to reintroducing indigenous crayfish would also benefit from such knowledge. Studies of the prevalence of pathogenic viruses and microorganisms in water and the environment based on real-time PCR are rapidly expanding (Smith \& Osborn 2009), but to date Oomycetes have been largely ignored. Here we present a real-time PCR-based approach for direct monitoring of $A$. astaci in aquatic environments. The practical performance is demonstrated on water samples from aquatic systems hosting infected signal crayfish.

\section{MATERIALS AND METHODS}

Preparation of spore units. In order to obtain quantitative units of Aphanomyces astaci for initial tests, spores were produced following the procedure described by Cerenius et al. (1988) with some minor modifications that included use of (1) smaller volumes (30 ml fluid in $50 \mathrm{ml}$ falcon tubes), (2) a sterile scalpel for fragmentation of hyphae and (3) autoclaved $\left(121^{\circ} \mathrm{C}\right.$, $15 \mathrm{~min}$ ) water from a fish tank housing salmon parr instead of lake water. Two confirmed strains of $A$. astaci (VI03628 and VI04850, corresponding to EMBL/ GenBank accession nos. AM947024 and FR694923 respectively) were used for spore production. These strains had previously been isolated from infected noble crayfish during crayfish plague outbreaks in the Halden water course (Norway) in 2005 and 2008, respectively. The strains are maintained on PG-1 (Söderhall et al. 1978) agar in the culture collection at the National Veterinary Institute (NVI), Norway. Unavoidably, the obtained spore suspension consisted of both spores and cysts, but both units contain one single genome and are in the present study referred to as spores or spore units. The spores produced were counted using a Brüker-Türk haemocytometer (W. Schreck, Hofheim/TS) on a light microscope at $10 \times$ magnification. A 10-fold dilution series using sterile distilled $\mathrm{H}_{2} \mathrm{O}$ as diluent was prepared, starting at $10^{4}$ spores $100 \mathrm{ul}^{-1}$ down to 1 spore $100 \mathrm{ul}^{-1}$. The spore dilutions were used immediately after preparation to avoid settlement of cysts or formation of new cysts in the tubes.

Preparation of spiked water samples. In order to test the sensitivity of the chosen real-time PCR assay (Vrålstad et al. 2009) with reference to spore units of Aphanomyces astaci with and without a filtration step, the following samples were prepared. Five spore suspensions (the control samples) containing approximately $1,10,10^{2}, 10^{3}$ and $10^{4}$ spores in $100 \mu$ l were 
transferred directly into $2 \mathrm{ml}$ Eppendorf tubes. Further, $100 \mu \mathrm{l}$ of the same spore suspensions were filtered (filter samples) on polycarbonate membrane filters (Millipore Isopore ${ }^{\mathrm{TM}}, 3 \mu \mathrm{m}$ pore size, $47 \mathrm{~mm}$ diameter) using the Microfil ${ }^{\circledR}$ Filtration System (Millipore). Each filter was loosely folded twice and transferred to a $2 \mathrm{ml}$ Eppendorf tube using a sterile forceps. For each spore suspension, 10 replicate samples were prepared for both control and filter samples. The tubes were then frozen at $-80^{\circ} \mathrm{C}$ awaiting DNA extraction.

To simulate real-life samples from natural water bodies, and to test the detectability of Aphanomyces astaci spores in such samples, water samples from 3 different lakes close to Oslo (Norway) with different water quality were collected. The 3 locations were Lutvann (oligotrophic), Årungen (eutrophic) and Sværsvann (dystrophic, stained by humic substances). A selection of limnological characteristics from these lakes is given in Table 1. Water samples of 11 (surface water collected 13 May 2009) from each lake were spiked with $100 \mu \mathrm{l}$ of 2 spore suspensions that contained approximately 10 and $10^{3}$ spores, respectively (5 replicate samples per concentration, per lake). The water samples were filtered on membrane filters and processed as described in the preceding paragraph. For the controls, $100 \mu \mathrm{l}$ of the same spore suspensions were added directly to $2 \mathrm{ml}$ Eppendorf tubes (5 replicates for each control concentration).

Sampling and preparation of freshwater samples from a signal crayfish farm. To test the validity of the method, water samples and net haul samples were collected from ponds with signal crayfish of unknown carrier status at 3 crayfish farms in Finland (6 to 8 August 2009). Farm A consists of 1 indoor concrete tank and 2 outdoor ponds. The indoor tank is used as a holding tank for market-sized crayfish, collected from crayfish trappers from southern Finland, whereas under-market-sized crayfish are stocked in the outdoor ponds for growth. Farm B consists of 1 pond of roughly 1 hectare. The pond is used for recreational crayfish trapping for tourists. Farm C consists of 1 pond with a surface area of $400 \mathrm{~m}^{2}$. Crayfish farm data, including estimates of the average number of crayfish individuals per area and water volume, are summarised in Table 2.

In all farms, water samples were collected at the bottom by submerging a Limnos water sampler (Hydro-Bios) to the bottom. Net haul samples were collected by a plankton net $(10 \mu \mathrm{m}$ mesh size), towed horizontally at approximately 0.5 to $1 \mathrm{~m}$ depth for $5 \mathrm{~m}$. The number of water and net haul samples for each farm varied from 3 to 5 (details in 'Results'). Also, 10 signal crayfish were collected from each pond (except the indoor holding tank at Farm A) to determine their carrier status: soft abdominal cuticle, the proximal joint of 2 anterior walking legs and telson (according to Oidtmann et al. 2006) were tested with Aphanomyces astaci-specific real-time PCR according to Vrålstad et al. (2009).

DNA isolation. DNA was extracted from the samples with a modified version of the CTAB extraction protocol used by Vrålstad et al. (2009). The samples were initially frozen at $-80^{\circ} \mathrm{C}$ in $2 \mathrm{ml}$ Eppendorf tubes. One millilitre of pre-heated $\left(65^{\circ} \mathrm{C}\right) \mathrm{CTAB}$ buffer $\left(20 \mathrm{~g} \mathrm{l}^{-1}\right.$ CTAB, $1.4 \mathrm{M} \mathrm{NaCl}, 0.1 \mathrm{M}$ Tris- $\mathrm{HCl}, 20 \mathrm{mM} \mathrm{Na}_{2}$ EDTA) with $1 \% 2$-mercaptoethanol was added to the filter samples, followed by vortexing for 10 to $15 \mathrm{~s}$ and subsequent freezing $\left(-80^{\circ} \mathrm{C}\right.$ for minimum $\left.30 \mathrm{~min}\right)$. The samples were then heated to $65^{\circ} \mathrm{C}$ and $10 \mu \mathrm{l}$ RNase A solution $\left(10 \mathrm{mg} \mathrm{ml}^{-1}\right)$ was added, followed by mixing and incubation at $65^{\circ} \mathrm{C}$ for $30 \mathrm{~min}$. Subsequently, $10 \mu \mathrm{l}$ of Proteinase $\mathrm{K}\left(20 \mathrm{mg} \mathrm{ml}^{-1}\right)$ was added, followed by mixing and incubation at $65^{\circ} \mathrm{C}$ for $30 \mathrm{~min}$. Chloroform (600 $\mathrm{\mu l}$ ) was added and mixed by manual shaking for $15 \mathrm{~s}$ (this step dissolves the polycarbonate filter). The tubes were centrifuged $(16000 \times g, 15 \mathrm{~min}), 800 \mu \mathrm{l}$ of the aqueous phase was transferred to new tubes, $480 \mu \mathrm{l}$ of isopropanol (stored at $-20^{\circ} \mathrm{C}$ ) was added and mixed in by inversion, and the sample was then incubated at room temperature for $15 \mathrm{~min}$ to precipitate the

Table 1. Selected limnological characteristics of the lakes used for simulation of real-life samples. Total P: total phosphorus in surface water; water colour: staining by humic matter compared to a standard solution; Pt: platinum

\begin{tabular}{|c|c|c|c|c|c|c|}
\hline Lake & $\begin{array}{l}\text { Trophic } \\
\text { state }\end{array}$ & $\begin{array}{c}\text { Total } \\
\mathrm{P} \\
\left(\mu \mathrm{g} \mathrm{l}^{-1}\right)\end{array}$ & $\begin{array}{l}\text { Secchi } \\
\text { depth } \\
(\mathrm{m})\end{array}$ & $\begin{array}{l}\text { Conduc- } \\
\text { tivity } \\
\left(\mathrm{mS} \mathrm{m}^{-1}\right)\end{array}$ & $\begin{array}{c}\text { Water } \\
\text { colour } \\
\left(\mathrm{mg} \mathrm{Pt}^{-1}\right)\end{array}$ & $\mathrm{pH}$ \\
\hline Lutvann & Oligotrophic & $<5$ & $>10$ & $\sim 6$ & $<5$ & $\sim 7$ \\
\hline Sværsvann & Dystrophic & 18 & $<3$ & 4.5 & $>60$ & $<7$ \\
\hline Årungen & Eutrophic & $25-60$ & $<1-2.5$ & 15 & $\sim 10-20$ & $7-9.5$ \\
\hline
\end{tabular}

Table 2. Pacifastacus leniusculus. Summary data for the crayfish farms. Farm A consists of 3 locations: A1 (indoor tank), A2 (outdoor pond 1) and A3 (outdoor pond 2). Farms B and $\mathrm{C}$ are both outdoor ponds

\begin{tabular}{|lcrrrrr|}
\hline Farm & $\begin{array}{c}\text { Mean } \\
\text { depth } \\
(\mathrm{m})\end{array}$ & $\begin{array}{c}\text { Area } \\
\left(\mathrm{m}^{2}\right)\end{array}$ & $\begin{array}{c}\text { Volume } \\
\left(\mathrm{m}^{3}\right)\end{array}$ & $\begin{array}{c}\text { No. of } \\
\text { crayfish }\end{array}$ & $\begin{array}{c}\text { Crayfish per } \\
\text { unit area } \\
\left.\text { (ind. } \mathrm{m}^{-2}\right)\end{array}$ & $\begin{array}{c}\text { Crayfish per } \\
\text { unit volume } \\
\left.\text { (ind. } \mathrm{m}^{-3}\right)\end{array}$ \\
\hline A1 & 0.35 & 40 & 14 & 1500 & 37.5 & 107.1 \\
A2 & 1.3 & 1000 & 1300 & 2000 & 2.0 & 1.5 \\
A3 & 1.5 & 1000 & 1500 & 4000 & 4.0 & 2.7 \\
B & 2.5 & 10000 & 25000 & 10000 & 1.0 & 0.4 \\
C & 1 & 400 & 400 & 1000 & 2.5 & 2.5 \\
\hline
\end{tabular}


DNA. The tubes were centrifuged $(16000 \times g, 15 \mathrm{~min})$ and the supernatant carefully removed. The pellets were washed with $300 \mu \mathrm{l}$ of $70 \%$ ethanol (stored at $-20^{\circ} \mathrm{C}$ ) and centrifuged $(16000 \times g, 5 \mathrm{~min})$. The supernatants were carefully removed and the pellets were dried for approximately 15 min using a vacuum dryer or heating block at $50^{\circ} \mathrm{C}$. The pellets were then resuspended in sterile TE buffer. An environmental control (tube with sterile water left open on laboratory work bench during entire analytical process) and extraction blank control (sample tube subjected to DNA extraction process but without sample material) were included in the PCR to control for potential carry-over contamination (Vrålstad et al. 2009).

Real-time PCR. A TaqMan ${ }^{\circledR}$ minor groove binder (MGB) quantitative real-time PCR (qPCR) assay (Vrålstad et al. 2009) was used for the detection of Aphanomyces astaci in the sample DNAs. This assay targets a $59 \mathrm{bp}$ sequence motif in the internal transcribed spacer 1 (ITS1) of the nuclear ribosomal gene cluster unique to A. astaci. Amplification and detection was performed on the Mx3005P qPCR system (Stratagene) in a total volume of $25 \mu \mathrm{l}$ containing $12.5 \mu \mathrm{l}$ Universal PCR Master Mix (Applied Biosystems), $500 \mathrm{nM}$ of forward (AphAstITS-39; 5'-AAG GCT TGT GCT GGG ATG TT$\left.3^{\prime}\right)$ and reverse primers (AphAstITS-97; 5'-CTT CTT GCG AAA CCT TCT GCT A-3'), 200 nM MGB probe (AphaAstITS-60; 5'-6-FAM-TTC GGG ACG ACC CMGB-NFQ-3'), $1.5 \mu \mathrm{l}$ sterile Milli-Q water and $5 \mu \mathrm{l}$ DNA template. Each DNA extract was always tested with an undiluted and a 10-fold diluted replicate. Also, 3 replicate qPCR runs were conducted per DNA extract from samples of the spore dilution series and the spiked natural water samples. The PCR programme consisted of an initial decontamination step of $2 \mathrm{~min}$ at $50^{\circ} \mathrm{C}$ to allow optimal uracil-DNA glycosylase (UNG) enzymatic activity, followed by $10 \mathrm{~min}$ at $95^{\circ} \mathrm{C}$ to activate the DNA polymerase, deactivate the UNG and denature the template DNA, and successively 50 cycles of $15 \mathrm{~s}$ at $95^{\circ} \mathrm{C}$ and $60 \mathrm{~s}$ at $58^{\circ} \mathrm{C}$. The qPCR data was analysed using MxPro software v. 4.10 (Stratagene).

Quantification. In the present study we adopt the term PCR-forming units (PFU) as defined by HolstJensen \& Berdal (2004) and also used in Vrålstad et al. (2009). A PFU corresponds to a single unit of a DNA target, in our case an ITS copy, that is amplifiable by PCR (i.e. not damaged or otherwise inhibited). Notably, the PFU may contain aggregated target sequence copies. In order to estimate the number of PFU from each spore concentration, 4 calibrant points from a standard series as described in Vrålstad et al. (2009) were included in each qPCR run in addition to the unknown samples. The limit of detection (LOD) and the limit of quantification (LOQ) for the specific Aphanomyces astaci TaqMan ${ }^{\circledR}$ MGB qPCR assay were previously estimated to be 5 and $50 \mathrm{PFU}$, respectively (Vrålstad et al. 2009). In the present study, all spore concentrations, both the control and filter samples, were detected and quantified based on the same detection and quantification limits. If the difference in the cycle threshold $\left(C_{\mathrm{t}}\right)$ value $\left(\Delta C_{\mathrm{t}}\right)$ between the undiluted and $10 \times$ diluted DNA was $<3$, this was interpreted as evidence of inhibition of the qPCR for undiluted DNA. In the absence of inhibition, the qPCR results from the undiluted DNA extracts were used as the basis for PFU quantification. In the presence of inhibition, the qPCR results from the 10x diluted DNA extracts were used.

Diminishing amplification inhibition in real-time PCR. Humic substances, which are often present in water from freshwater lakes, are relatively hard to remove during DNA extraction and could inhibit enzyme activity during PCR amplification. Bovine serum albumin (BSA) has been shown to diminish the inhibitory effects of such substances (Kreader 1996). Due to clear inhibition in our spiked natural water samples, we tested if amplification inhibition was diminished with use of BSA in the qPCR reaction mix. All spiked water samples were re-tested with 4 different concentrations of BSA $(5 \mathrm{mg}$ in $0.25 \mathrm{ml}$; Fermentas) added to the reaction mix to final reaction concentrations of $0.1,0.3,0.5$ and $1.0 \mu \mathrm{g} \mathrm{ll}^{-1}$. Additionally, we also re-tested all spiked water samples and crayfish pond samples using the recently developed TaqMan ${ }^{\circledR}$ Environmental Master Mix (Applied Biosystems).

Statistics. To test if there were significant differences between the qPCR results of the control samples and filter samples, a linear mixed-effects model (including random slopes and intercepts for the replicates) was used in order to account for the dependence structure of the data. Based on the full model (i.e. including interaction term for the fixed effects), the random structure giving the smallest Akaike's information criterion (AIC) value was selected (Zuur et al. 2009). Results from both undiluted and diluted samples were included in the tests. Statistical tests were performed in the software R, v. 2.9.0 (R Development Core Team 2009), using the package nlme for mixed-effects modelling (Zuur et al. 2009).

\section{RESULTS}

\section{Detection and quantification of Aphanomyces astaci spores}

We detected spore concentrations down to approximately 1 spore sample ${ }^{-1}$ (Fig. 1), which equals $\sim 0.05$ spore per PCR reaction since the DNA was eluted in 


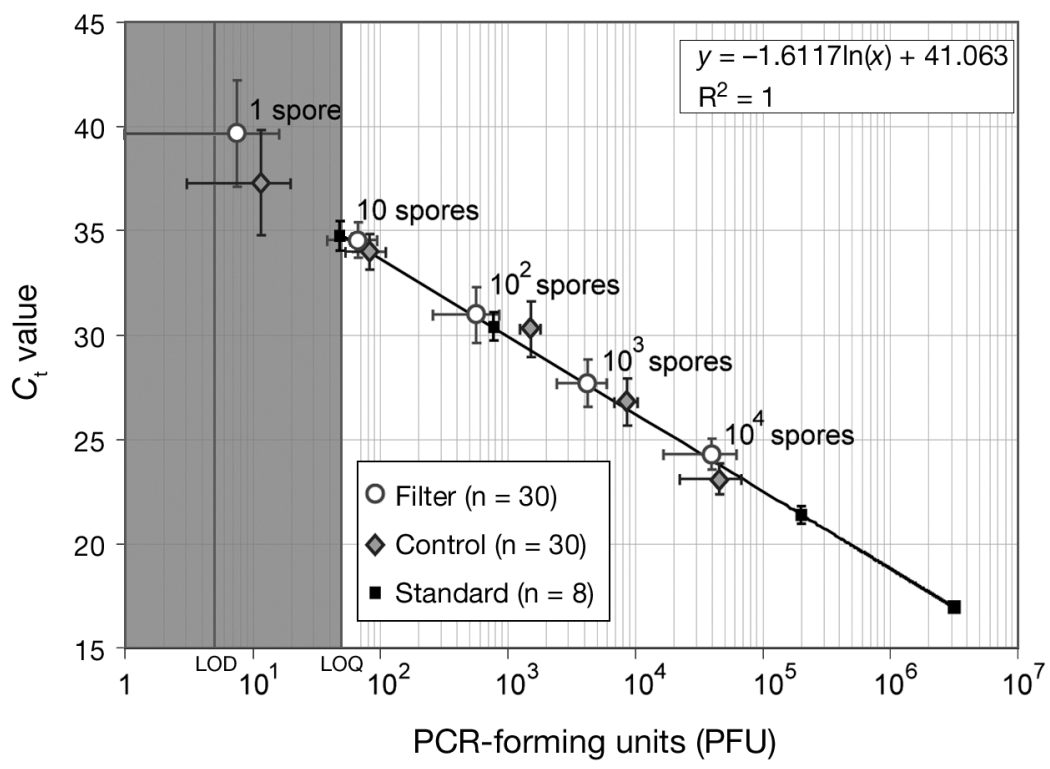

Fig. 1. Aphanomyces astaci. Mean cycle threshold $\left(C_{t}\right)$ values $( \pm \mathrm{SD})$ vs. mean PCR-forming units (PFU) $( \pm \mathrm{SD})$ of the control and filter samples of the spore dilution series plotted against the standard curve consisting of 4 calibrant points. Shaded area is below the limit of quantification (LQR). Each point represents 10 replicates of each spore concentration and each replicate was run 3 times on quantitative PCR (qPCR). LOD = limit of detection the 10th and 90th percentiles (Table 3). Consequently, when using 0.05 units of the original DNA sample, the LOD corresponds approximately to $\sim 0.7$ spore and the LOQ approximately to $\sim 7$ spores in the original sample, respectively.

We observed a small but significant increase in the $C_{\mathrm{t}}$ value $(0.84 \pm 0.16 \mathrm{SE}$, $\mathrm{p}<0.0001)$ of undiluted Aphanomyces astaci DNA for filter samples above LOQ compared to control samples (Fig. 2a; and the Supplement at www.int-res.com/ articles/ suppl/d095p009_supp.pdf), but there was no significant linear interaction between spore concentration and filter treatment. However, the strength of the filter effect varied with spore concentration replicate (estimated SD of random slopes was 0.97$)$. For diluted $(\times 10)$ DNA, on the other hand, there was no significant difference in the $C_{\mathrm{t}}$ value between filtered and unfiltered samples $(0.09 \pm 0.24 \mathrm{SE}, \mathrm{p}=0.70$; Fig. $2 \mathrm{a}$ and the Supplement).
$100 \mu \mathrm{l}$ of TE buffer and only $5 \mu \mathrm{l}$ of this genomic DNA sample was used in the subsequent qPCR reaction. Of single spore samples, $73.3 \%$ (filter) and 80\% (controls) of the samples were amplified, of which $43.3 \%$ (filter) and $56.7 \%$ (controls) yielded a $C_{\mathrm{t}}$ value corresponding to $>5 \mathrm{PFU}$ (LOD) extrapolated from the standard curve. Further, of the 10 spore samples, $63.3 \%$ (filter) and $76.7 \%$ (control) were detected above the LOQ ( $\geq 50$ PFU). Rough PFU estimates (based on the median and not the mean due to skewed data) per spore based on all control spore dilutions ( 1 to $10^{4}$ spores) indicate that a single spore contains approximately $\sim 138 \mathrm{PFU}$, although wide variability of the estimate is shown by

Table 3. Aphanomyces astaci. Estimated PCR-forming units (PFU) per spore, calculated as: spore dilution PFU estimate of control samples $\times 20$ (as PCR reaction is based on 0.05 of whole DNA sample) / no. of spores. PCR reactions of 10 spore replicate samples in PCR triplicates

\begin{tabular}{|lcc|}
\hline $\begin{array}{l}\text { No. of spores } \\
\text { in dilution }\end{array}$ & $\begin{array}{c}\text { Median PFU } \\
\text { estimate spore } \\
\text { (10th to 90th percentile) }\end{array}$ & $\begin{array}{c}\text { No. of PCR } \\
\text { reactions }\end{array}$ \\
\hline 1 & $149(0-500)$ & 30 \\
10 & $177(78-219)$ & 30 \\
$10^{2}$ & $346(68-457)$ & 30 \\
$10^{3}$ & $160(56-247)$ & 30 \\
$10^{4}$ & $92(36-132)$ & 30 \\
Median total & $138(39-448)$ & 150 \\
\hline
\end{tabular}

\section{Detection and quantification of Aphanomyces astaci spores in spiked natural water samples}

The qPCR amplification showed clear signs of inhibition for all samples obtained from natural water bodies compared to controls. Neither 10 nor 1000 spores were

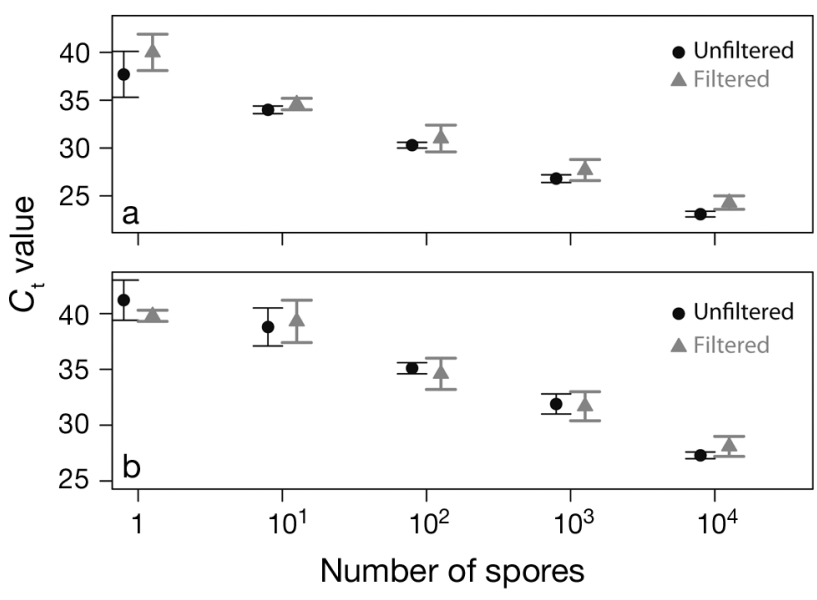

Fig. 2. Aphanomyces astaci. Mean cycle threshold $\left(C_{\mathrm{t}}\right)$ values $( \pm \mathrm{SD})$ from control and filter samples of the spore dilution series, for (a) undiluted and (b) diluted DNA. For each replicate, the mean $C_{\mathrm{t}}$ value for 3 repeated measures was used. The observed difference in $C_{\mathrm{t}}$ values between filter and control samples was significant $(0.84 \pm 0.16 \mathrm{SE}, \mathrm{p}<0.0001)$ for the undiluted $A$. astaci DNA samples, but not the $10 \times$ diluted DNA samples $(0.09 \pm 0.24 \mathrm{SE}, \mathrm{p}=0.70)$ 
possible to detect in the spiked natural water samples using the standard qPCR reagents (Fig. 3). BSA reduced the inhibition, but the needed concentration varied between the different water samples. For eutrophic water, $0.1 \mu \mathrm{g} \mathrm{\mu l}^{-1} \mathrm{BSA}$ in the PCR reaction was sufficient to remove inhibition, while for the oligotrophic water, $0.3 \mu \mathrm{g} \mathrm{ll}^{-1}$ BSA efficiently removed inhibition. The inhibition was most prominent for humicrich water samples, and even a BSA concentration of $0.5 \mu \mathrm{g} \mathrm{ll}^{-1}$ in the PCR reaction did not fully remove the inhibition. However, the TaqMan ${ }^{\circledR}$ Environmental Master Mix turned out to be more efficient than BSA, and removed close to $100 \%$ of the previously observed inhibition for all the different natural water samples (Fig. 3).

\section{Detection and quantification of Aphanomyces astaci in crayfish and water from crayfish farms}

From Farms A and B, 18 (90\%) and 8 (89\%) crayfish tested positive for Aphanomyces astaci in at least one of the tested tissue samples, respectively. In general, tissue samples of telson and walking legs yielded higher frequencies of positive results than samples of soft abdominal cuticle (Table 4). For Farm C, none of the 10 crayfish were positive for A. astaci in any of the tested tissues (Table 4). Results from the water and net haul samples are summarised in Table 5. From Farm A, the 3 samples from the indoor pond contained on average $\sim 332$ A. astaci genome units (assumed spores) per litre based on the assumption that 1 spore contains $\sim 138$ PFU. The outdoor ponds hosted a considerably lower density of spores. From the 2 outdoor ponds of Farm A, 50 and $40 \%$ of the samples in Ponds 1 and 2 were positive, respectively (above LOD), but with one exception below LOQ. Hence, <7 spores were detected in all positive samples apart from one, in which about 33 spores were estimated (Table 3). For Farm B, which consisted only of one large pond, $<7$ and $\sim 18$ A. astaci spores were detected in 2 respective water samples, while the remaining water samples and net haul samples were negative. All samples from Farm C were negative.

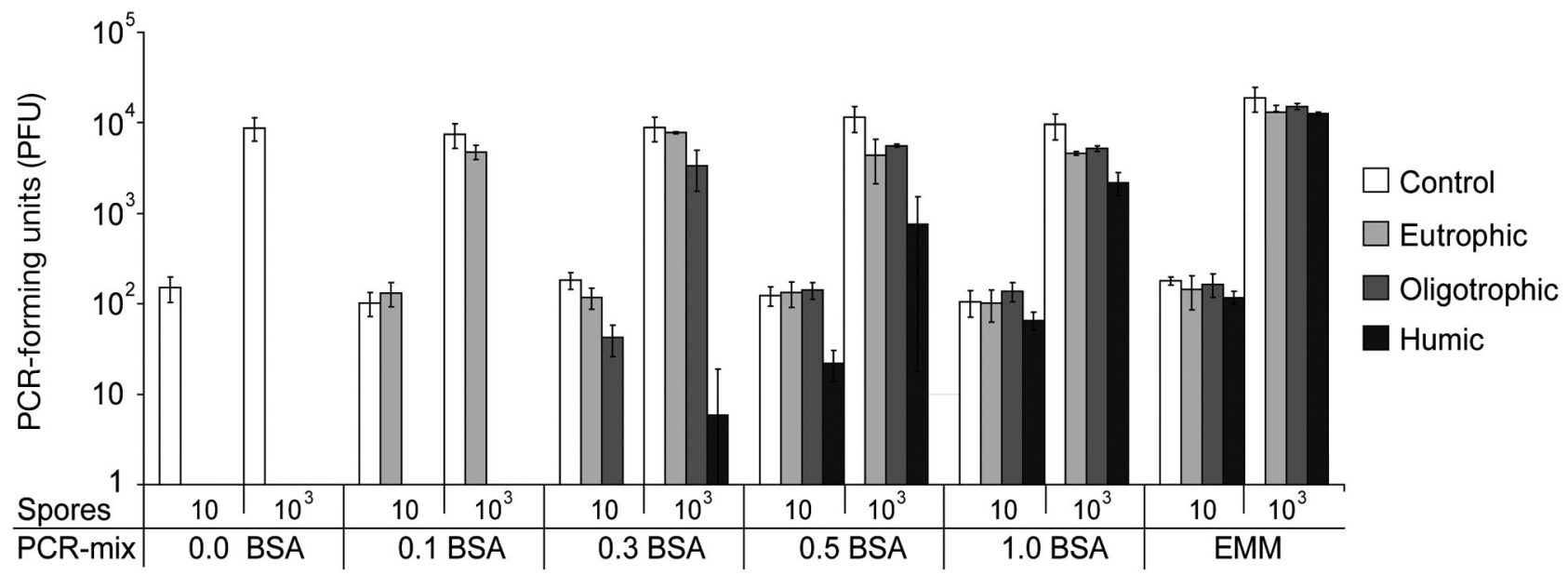

Fig. 3. Aphanomyces astaci. Quantitative PCR (qPCR) results in mean PCR-forming units (PFU) ( \pm SD) of undiluted DNA from natural water samples spiked with 10 or 1000 spores $1^{-1}$. Different concentrations of bovine serum albumin (BSA) in a standard PCR mix and Environmental Master Mix (EMM) were compared. Five replicate samples were used per spore suspension and location, and 3 qPCR repeats per sample replicate

Table 4. Aphanomyces astaci infecting Pacifastacus leniusculus. Real-time PCR results testing for A. astaci DNA in crayfish from each farm or pond except Pond A1. Crayfish testing positive: A. astaci DNA detected in at least one of the tested tissue samples $\left(\mathrm{n}=10\right.$ crayfish location $^{-1}$, except $\mathrm{n}=9$ for Farm B); PFU: PCR-forming units

\begin{tabular}{|c|c|c|c|c|c|c|c|}
\hline \multirow[t]{2}{*}{ Farm } & \multirow{2}{*}{$\begin{array}{c}\text { Crayfish } \\
\text { testing } \\
\text { positive (\%) }\end{array}$} & \multicolumn{2}{|c|}{ Cuticle -} & \multicolumn{2}{|c|}{$\longrightarrow$ Walking leg } & \multirow{2}{*}{$\begin{array}{c}\mathrm{PFU}^{\mathrm{T}} \\
(\mathrm{mean} \pm \mathrm{SD})\end{array}$} & \multirow{2}{*}{$\begin{array}{l} \\
\text { Positive } \\
\text { samples }(\%)\end{array}$} \\
\hline & & $\begin{array}{c}\mathrm{PFU} \\
(\mathrm{mean} \pm \mathrm{SD})\end{array}$ & $\begin{array}{c}\text { Positive } \\
\text { samples (\%) }\end{array}$ & $\begin{array}{c}\text { PFU } \\
(\text { mean } \pm \text { SD) }\end{array}$ & $\begin{array}{c}\text { Positive } \\
\text { samples (\%) }\end{array}$ & & \\
\hline $\mathrm{A} 2$ & 100 & $117 \pm 309$ & 40 & $552 \pm 853$ & 90 & $989 \pm 1290$ & 100 \\
\hline A3 & 80 & $13 \pm 28$ & 20 & $411 \pm 911$ & 50 & $90 \pm 191$ & 50 \\
\hline $\mathrm{B}$ & 89 & $107 \pm 289$ & 22 & $48 \pm 71$ & 44 & $267 \pm 534$ & 89 \\
\hline $\mathrm{C}$ & 0 & 0 & 0 & 0 & 0 & 0 & 0 \\
\hline
\end{tabular}


Table 5. Aphanomyces astaci. Estimated PCR-forming units (PFU) values and spore numbers in analysed DNA from various water samples and net hauls collected from the 3 signalcrayfish farms in Finland. All positive samples were detected above the limit of detection. Sample ID: indicates Farm A (Pond A1, A2 or A3), B or C, and either a water sample (WS) collected by a $1 \times 2 \mathrm{l}$ water sampler at the bottom of each pond, or a water filtrate collected by a plankton net sampler, a $2 \mathrm{~m}$ net haul $(\mathrm{NH})$ with $10 \mu \mathrm{m}$ mesh size. Volume refers to the actual volume analysed (in many cases, filter clogging prevented filtration of the whole sample; subsamples for parts of the sampled volume were made and analysed separately, but here the results have been pooled; net hauls were collected in a $100 \mathrm{ml}$ cup). Estimated no. of spores in sample based on median value of PFU estimate per spore (1 spore equals $138 \mathrm{PFU}$ in $100 \mu \mathrm{l}$ DNA sample)

\begin{tabular}{|c|c|c|c|c|}
\hline $\begin{array}{l}\text { Sample } \\
\text { ID }\end{array}$ & $\begin{array}{l}\text { Volume } \\
\text { (l) }\end{array}$ & $\begin{array}{l}\text { PFU in } \\
\text { PCR } \\
\text { reaction } \\
(5 \mu \mathrm{l} \text { DNA })\end{array}$ & $\begin{array}{c}\text { PFU in } \\
\text { original DNA } \\
\text { sample } \\
(100 \mu \mathrm{l} \text { DA })\end{array}$ & $\begin{array}{c}\text { Rough } \\
\text { spore } \\
\text { estimate } \\
\text { in sample }\end{array}$ \\
\hline A1_WS1 & 1 & 1907 & 38140 & 276 \\
\hline A1_WS2 & 1 & 2782 & 55640 & 403 \\
\hline A1_WS3 & 1 & 2181 & 43620 & 316 \\
\hline A2_WS1 & 1 & 0 & 0 & 0 \\
\hline A2_WS2 & 1 & $<50$ & $<10^{3}$ & $<7$ \\
\hline A2_NH1 & 0.1 & 0 & 0 & 0 \\
\hline A2_NH2 & 0.1 & $<50$ & $<10^{3}$ & $<7$ \\
\hline A3_WS1 & 0.35 & 0 & 0 & 0 \\
\hline A3_WS2 & 0.6 & $<50$ & $<10^{3}$ & $<7$ \\
\hline A3_WS3 & 0.3 & $<50$ & $<10^{3}$ & $<7$ \\
\hline A3_WS4 & 0.3 & 0 & 0 & 0 \\
\hline A3_WS5 & 0.8 & 0 & 0 & 0 \\
\hline A3_NH1 & 0.1 & $<50$ & $<10^{3}$ & $<7$ \\
\hline A3_NH2 & 0.1 & 0 & 0 & 0 \\
\hline A3_NH3 & 0.1 & 0 & 0 & 0 \\
\hline A3_NH4 & 0.1 & 0 & 0 & 0 \\
\hline A3_NH5 & 0.1 & 232 & 4641 & 33 \\
\hline B1_WS1 & 0.7 & 0 & 0 & 0 \\
\hline B1_WS2 & 0.8 & 0 & 0 & 0 \\
\hline B1_WS3 & 0.7 & 0 & 0 & 0 \\
\hline B1_WS4 & 0.4 & $<50$ & $<10^{3}$ & $<7$ \\
\hline B1_WS5 & 0.6 & 126 & 2526 & 18 \\
\hline B1_NH1 & 0.1 & 0 & 0 & 0 \\
\hline B1_NH2 & 0.1 & 0 & 0 & 0 \\
\hline B1_NH3 & 0.1 & 0 & 0 & 0 \\
\hline B1_NH4 & 0.1 & 0 & 0 & 0 \\
\hline B1_NH5 & 0.1 & 0 & 0 & 0 \\
\hline C1_WS1 & 1.6 & 0 & 0 & 0 \\
\hline C1_WS2 & 1.5 & 0 & 0 & 0 \\
\hline C1_WS3 & 1.5 & 0 & 0 & 0 \\
\hline C1_WS4 & 1.5 & 0 & 0 & 0 \\
\hline C1_NH1 & 0.1 & 0 & 0 & 0 \\
\hline C1_NH2 & 0.1 & 0 & 0 & 0 \\
\hline C1_NH3 & 0.1 & 0 & 0 & 0 \\
\hline
\end{tabular}

\section{DISCUSSION}

In the present study, we demonstrate that the capture of a single Aphanomyces astaci spore from a natural water body may be sufficient for subsequent molecular detection. Further, capturing 7 spores or more will allow for a crude quantification of the spore/genomic unit content of $A$. astaci in an individual water sample. A main source of uncertainty is the degree of heterogeneity of spore distribution in the water. In nature, heterogeneous distribution can be predicted both on a spatial and temporal scale. Hence, many samples of large water volumes must be analysed for an approximate estimate of the real-life situation of the spore dynamics in a lake. Nevertheless, our results demonstrate the sensitivity of the qPCR assay. Combined with optimised methods for concentrating large water volumes, the approach may allow for a specific pathogen search in natural environments even at very low spore levels.

Using spore suspensions of known spore content, we have demonstrated that the LOD ( $\leq 5 \mathrm{PFU})$ of the qPCR assay corresponds to the DNA content of approximately 0.7 spore, equivalent to 0.035 spore units per PCR reaction (given our experimental setup). Similarly, we have established that the LOQ (= 50 PFU) corresponds to the DNA content of approximately 7 spores, equivalent to 0.35 spore units per PCR. This is possible because the target DNA (ITS1) is present in multiple copies per genome (Long \& Dawid 1980). Use of multi-copy target genes and connected spacer regions such as the nuclear ribosomal gene cluster provides a huge benefit over single and low-copy genes due to multiple-fold increased likelihood of detection. Assuming that the number of spores in our spore dilutions were correctly estimated, our results indicate that one Aphanomyces astaci spore includes on average 138 PFU (amplifiable ITS copies). This should of course be taken as a very rough estimate that includes many sources of uncertainty (reflected in the percentile variation) including measuring errors in the initial spore counting, but illustrates nevertheless the power of ITS as target DNA when screening the environment for low concentrations of single-cell organisms. A possible way to further reduce the detection limit would be to up-concentrate the DNA by initial elution in smaller volumes and to use larger template DNA volumes per qPCR reaction.

The probe and primers used in the qPCR assay are highly specific to Aphanomyces astaci and have been tested against several Saprolegniaceae, including the closely related $A$. invadans and $A$. frigidophilus (Vrålstad et al. 2009). However, unknown diversity of putative closely related Aphanomyces spp. constitutes a challenge with regards to false positives. In a recent study (Wolinska et al. 2009), 3 unknown Aphanomyces taxa were discovered as parasites in Daphnia spp. in European lakes based on sequence information from nuclear ribosomal ITS region. These species grouped together with $A$. invadans and A. frigidophilus. It is therefore important to be cautious when interpreting 
results based on real-time PCR data alone. In some cases, particularly if detection of A. astaci is unexpected, the use of additional confirmative tools such as conventional A. astaci-specific PCR described by Oidtmann et al. (2006) and DNA sequencing may be necessary to verify the results, provided there is a sufficient amount of target DNA in the sample. Future studies employing pyrosequencing of specifically amplified oomycete amplicons from natural water samples would indeed contribute to a better understanding of the natural diversity of Aphanomyces spp. and accompanying ITS-sequence variation that may challenge the present diagnostic assays for specific detection of A. astaci.

There are several potential sources of DNA loss during the processes of sampling, filtration and DNA extraction. Filtration could be expected to be a source of DNA loss if the captured spores were squeezed or burst open due to the vacuum pumping system, and consequently escaped as squeezed spores or free DNA through the filter pores. However, our results indicate that DNA is not lost during filtration or DNA extraction from filters, but that the filter itself may lead to minor inhibition of the qPCR detection of undiluted DNA samples.

Detection of microorganisms from laboratory water samples is usually straightforward, but natural waters contain several substances that potentially hamper molecular detection. Spiked natural water samples with low levels of Aphanomyces astaci spores simulating the real challenges we may face in the attempt to detect low levels of $A$. astaci in aquatic freshwater habitats confirmed that humic acids, which are commonly present in crayfish lakes, most severely inhibit PCR amplification. Use of BSA in the PCR mix, which has previously been reported to diminish humic acids inhibition (Kreader 1996, Reuter et al. 2009), was in the present study relatively efficient at a concentration of $0.5 \mu \mathrm{g} \mathrm{\mu l}^{-1}$. However, the TaqMan ${ }^{\circledR}$ Environmental Master mix proved even more efficient and removed close to $100 \%$ of the observed qPCR inhibition from all water samples tested.

As the primary aim of the present study was to develop an approach for Aphanomyces astaci spore detection that would work in natural and semi-natural aquatic environments inhabited by crayfish, the successful detection of $A$. astaci spores directly from the 2 farms that hosted infected signal crayfish was a first breakthrough. Further, no positives were detected in water samples from the pond where no crayfish tested positive for A. astaci in any of the tested tissue samples. Even though 10 crayfish testing negative for $A$. astaci is insufficient to claim a negative carrier status of the signal crayfish population of Farm $C$, the apparent low prevalence of $A$. astaci compared to the other farms suggests that few or no spores of $A$. astaci would be present in the water. In this respect, the negative water samples provide indirect support for the specificity of the $\mathrm{qPCR}$ since no putative false positives were observed from the environmental samples of this farm. The highest levels of spores were detected in the indoor holding tank where large numbers of crayfish per water volume were kept in cages to be marketed later. The similar PFU values observed in these samples may indicate a relatively even distribution of spores, which could be expected due to thorough mixing of water in the indoor tank. On the other hand, the results from the outdoor ponds probably reflect a very low concentration of heterogeneously distributed spores. This could be explained by a more patchy distribution of crayfish, more water volume per individual and/or lower prevalence of A. astaci leading to heterogeneous spore release, fewer spores per water volume and consequently reduced likelihood of capturing spores in a water sample. Increased sample number or sample volume seems therefore essential for increased detection probability in systems with low spore density.

In the present study, clogging hampered the filtration of larger water volumes. Depending on the turbidity of the water, it was only possible to process water volumes from 0.3 to $1 \mathrm{l}$ per membrane filter. Increased water volume per sample will require other filters or other filtration methods than applied here. We are therefore considering alternative filtration methods for further studies, e.g. ultrafiltration systems that have been described for filtration of microbes from drinking water (Hill et al. 2007, Lindquist et al. 2007, Francy et al. 2009). Provided one uses optimised methods for sampling and concentration of large water volumes, direct detection of Aphanomyces astaci from environmental freshwater samples will become a valuable tool both for monitoring purposes and basic research on the ecology and spore dynamics of A. astaci in natural freshwater systems. The approach may also find application in management of wild noble crayfish stocks, improved aquaculture practices and more targeted conservation actions. Still, serious obstacles must be overcome before detection of trace levels of $A$. astaci from large water volumes is realistic, e.g. for the purpose of unveiling small numbers of illegally introduced carrier crayfish, or declaring a locality free of crayfish-plague infection. These challenges are tightly linked to sampling and filtration capacity and technology, or alternatively more advanced spore-capturing technologies.

Acknowledgements. This work was funded by the Norwegian Research Council (CPmonitor, NRC project 183986) through the programme 'Norwegian environmental research towards 2015'. We are grateful to R. F. Fristad at the Norwegian Veterinary Institute for technical assistance and to S. Viljamaa-Dirks for providing advice with regards to Aphanomyces 
astaci spore production. We also thank 3 crayfish farmers from Finland, I. Raukola, T. Kanervaara and T. Mamia, for kindly opening their farms to us.

\section{LITERATURE CITED}

Cerenius L, Söderhall K (1984) Repeated zoospore emergence from isolated spore cysts of Aphanomyces astaci. Exp Mycol 8:370-377

Cerenius L, Söderhall K, Persson M, Ajaxon R (1988) The crayfish plague fungus Aphanomyces astaci: diagnosis, isolation and pathobiology. Freshw Crayfish 7:131-144

> Francy DS, Bushon RN, Brady AMG, Bertke EE and others (2009) Comparison of traditional and molecular analytical methods for detecting biological agents in raw and drinking water following ultrafiltration. J Appl Microbiol 107: 1479-1491

Hall L, Unestam T (1980) The effect of fungicides on survival of the crayfish plague fungus, Aphanomyces astaci, Oomycetes, growing on fish scales. Mycopathologia 72: $131-134$

> Hill VR, Kahler AM, Jothikumar N, Johnson TB, Hahn D, Cromeans TL (2007) Multistate evaluation of an ultrafiltration-based procedure for simultaneous recovery of enteric microbes in 100-liter tap water samples. Appl Environ Microbiol 73:4218-4225

Hochwimmer G, Tober R, Bibars-Reiter R, Licek E, Steinborn R (2009) Identification of two GH18 chitinase family genes and their use as targets for detection of the crayfish-plague oomycete Aphanomyces astaci. BMC Microbiol 9:184

Holdich DM, Reynolds JD, Souty-Grosset C, Sibley PJ (2009) A review of the ever increasing threat to European crayfish from non-indigenous crayfish species. Knowl Manag Aquat Ecosyst 394-395:11

Holst-Jensen A, Berdal KG (2004) The modular analytical procedure and validation approach and the units of measurement for genetically modified materials in foods and feeds. J AOAC Int 87:927-936

Johnsen SI, Vrålstad T (2009) Signalkreps og krepsepest i Haldenvassdraget — forslag til tiltaksplan. NINA Rapport 474. Norsk institutt for naturforskning (NINA), Lillehammer

Jussila J, Ojala K, Mannonen A (2008) Noble crayfish (Astacus astacus) reintroduction project in the River Pyhäjoki, western Finland: a case study. Freshw Crayfish 16:51-56

Kreader CA (1996) Relief of amplification inhibition in PCR with bovine serum albumin or T4 gene 32 protein. Appl Environ Microbiol 62:1102-1106

Lindquist HDA, Harris S, Lucas S, Hartzel M, Riner D, Rochele P, DeLeon R (2007) Using ultrafiltration to concentrate and detect Bacillus anthracis, Bacillus atrophaeus subspecies globigii, and Cryptosporidium parvum in 100liter water samples. J Microbiol Methods 70:484-492

Long EO, Dawid IB (1980) Repeated genes in eukaryotes. Annu Rev Biochem 49:727-764

Oidtmann B, Bausewein S, Holzle L, Hoffmann R, Witten-

Editorial responsibility: Grant Stentiford,

Weymouth, UK brink M (2002) Identification of the crayfish plague fungus Aphanomyces astaci by polymerase chain reaction and restriction enzyme analysis. Vet Microbiol 85:183-194

> Oidtmann B, Schaefers N, Cerenius L, Söderhall K, Hoffmann RW (2004) Detection of genomic DNA of the crayfish plague fungus Aphanomyces astaci (Oomycete) in clinical samples by PCR. Vet Microbiol 100:269-282

Oidtmann B, Geiger S, Steinbauer P, Culas A, Hoffmann RW (2006) Detection of Aphanomyces astaci in North American crayfish by polymerase chain reaction. Dis Aquat Org 72:53-64

R Development Core Team (2009) R: a language and environment for statistical computing. R Foundation for Statistical Computing, Vienna

Reuter T, Xu WP, Alexander TW, Stanford K, Xu Y, McAllister TA (2009) Purification of polymerase chain reaction (PCR)amplifiable DNA from compost piles containing bovine mortalities. Bioresour Technol 100:3343-3349

Smith CJ, Osborn AM (2009) Advantages and limitations of quantitative PCR (Q-PCR)-based approaches in microbial ecology. FEMS Microbiol Ecol 67:6-20

Söderhall K, Cerenius L (1999) The crayfish plague fungus: history and recent advances. Freshw Crayfish 12:11-35

Söderhall K, Svensson E, Unestam T (1978) Chitinase and protease activities in germinating zoospore cysts of the parasitic fungus, Aphanomyces astaci, Oomycetes. Mycopathologia 64:9-11

Unestam T (1966) Studies on crayfish plague fungus Aphanomyces astaci. 2. Factors affecting zoospores and zoospore production. Physiol Plant 19:1110-1119

- Unestam T (1969) On the adaptation of Aphanomyces astaci as a parasite. Physiol Plant 22:221-235

Unestam T (1972) On the host range and origin of the crayfish plague fungus. Rep Inst Freshw Res Drottningholm 52: 192-198

Vrålstad T, Hastein T, Taugbol T, Lillehaug A (2006) Krepsepest-smitteforshold i norske vassdrag og forebyggende tiltak mot videre spredning av krepsepest. Veterinærinstituttets rapportserie 6-2006. National Veterinary Institute, Oslo. Available at: www.vetinst.no/nor/content/ download/505/4141/file/Rapport_06_2006.pdf

Vrålstad T, Knutsen AK, Tengs T, Holst-Jensen A (2009) A quantitative TaqMan (R) MGB real-time polymerase chain reaction based assay for detection of the causative agent of crayfish plague Aphanomyces astaci. Vet Microbiol 137:146-155

Westman K (2000) Comparison of the crayfish Pacifastacus leniusculus Dana, a species introduction into Finland, with the native species, Astacus astacus L., in allopatry and sympatry. PhD thesis, University of Helsinki

Wolinska J, Giessler S, Koerner H (2009) Molecular identification and hidden diversity of novel Daphnia parasites from European lakes. Appl Environ Microbiol 75:7051-7059

Zuur AF, Ieno EN, Walker N, Saveliev AA, Smith GM (2009) Mixed effects models and extensions in ecology with $\mathrm{R}$. Springer, New York, NY

Submitted: October 13, 2010; Accepted: January 11, 2011

Proofs received from author(s): April 26, 2011 